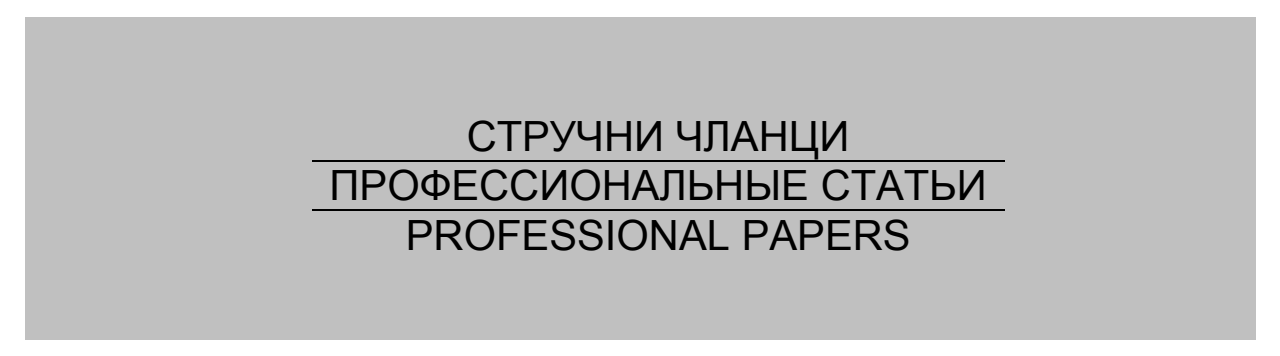

\title{
IMPROVED PERFORMANCES OF THE WIND INLET OF THE SAVONIUS ROTOR
}

\author{
Dejan D. Dinčića , Milan Z. Despotović ${ }^{b}$, \\ University of Kragujevac, Faculty of Engineering, \\ Kragujevac, Republic of Serbia \\ a e-mail: dincicdejan@gmail.com, \\ ORCID iD: Dorcid.org/0000-0001-9960-4055 \\ b e-mail: mdespotovic@kg.ac.rs, \\ ORCID iD: (iDorcid.org/0000-0003-3144-5945
}

https://dx.doi.org/10.5937/vojtehg65-10869

FIELD: Energy and Process Engineering ARTICLE TYPE: Professional Paper ARTICLE LANGUAGE: English

\section{Summary:}

In this study we analyzed the design changes through increasing vertical angles of the top and bottom plates of the wind inlet of a Savonius rotor, in order to obtain better results and better system performances. A designed wind inlet is placed in the front part of the rotor in order to prevent negative torque opposing rotor rotation. The geometric parameters of the wind inlet are determined to obtain optimal performances. Analyses and tests have shown that the increase of the vertical angles of the top and bottom plates on the wind inlet of a Savonius rotor leads to better rotor performances in comparison to the use of a classic wind inlet. It was found that the best results are achieved with increasing vertical angles of the top and bottom plates of the Savonius rotor wind inlet for a total of $15^{\circ}$, where the rotor speed is 395 revolutions per minute.

Keywords: vertical angles, wind, Savonius rotor, rotors, plates, wind inlet.

\section{Introduction}

The need for energy increases with the increase in population and higher energy consumption consequently increases the price of fossil fuels. At the same time, due to higher consumption of fossil fuels, there is a problem with global climate change caused by increased emissions of 
carbon dioxide released during the combustion of fossil fuels. Using renewable energy is an important goal of energy policy in the world (Frederikus, et al., 2015, p.298). Wind is an ecological source of energy that has huge potential to meet the energy needs of people as well as to mitigate climate change due to greenhouse gas emissions from fossil fuels (Frederikus, et al., 2015, p.298). This is why wind energy is an important resource of clean energy (Mahmoud, et al., 2012, p.19), which has received considerable attention in the last decade. It is estimated that there is about 10 million MW of wind energy available on Earth (Frederikus, et al., 2015, p.298). Wind energy is very useful as a clean energy source and wind turbines are the most important source of wind energy (Burçin, Mehmet, 2008b, p.3425). Wind power may to some extent contribute to energy production and many countries can use it through windmills. Global industry of windmill-produced energy, which dominates in Europe, North America and Asia, increased by about $29 \%$ in 2008 and exceeded $120 \mathrm{GW}$ (Terje, Susanne, 2014, p.197). Wind generators are used for converting wind energy into mechanical energy and for electricity production. There are different types of wind turbines with a vertical axis of rotation such as the Savonius rotor, Darius rotor, or H-Darius rotor. The examples of such windmills can be seen in Figure 1 (Frederikus, et al., 2015, p.298).

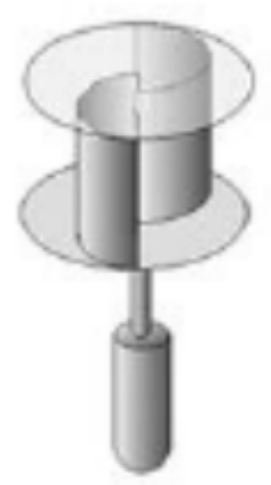

a)

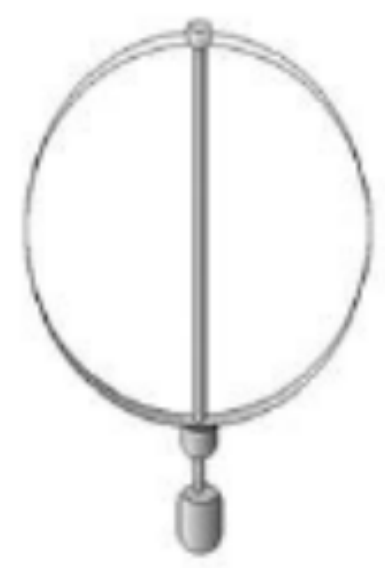

b)

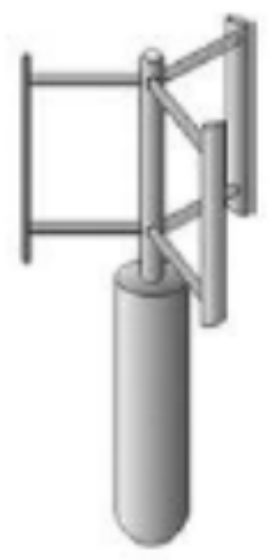

c)

Figure 1 - The windmill with a vertical axis of rotation of a) Savonius rotor, b) Darius rotor, c) H-Darius rotor Puc. 1 - Ветродвигатель с вертикальной осью вращения a) ротор Савониуса b) ротор Дариуса, с) ротор Х-Дариуса Слика 1 - Ветрењача са вертикалном осом ротације a) Савониусов ротор, b) Дариусов ротор, с) Х-Дариусов ротор 


\section{Savonius rotor}

A Savonius rotor is a wind rotor with a vertical axis invented by Finnish engineer Sigurd Savonius in 1925 (Burçin, Mehmet, 2008b, p.3425). Although these rotors have lower performances than usual wind rotors with vertical axis, they still have some advantages over others: they start to work on their own independently of the wind direction, they have a high starting torque at lower wind speeds, and a simpler and cheaper structure (Burçin, Mehmet, 2010, p.821). This motor has a simple design. It has good initial characteristics and functions at relatively low wind speeds. It is not necessary to direct such windmills, because they can work in all wind directions (Dobrev, Fawaz, 2011, p.712). However, a Savonius rotor has low aerodynamic efficiency. It is constructed of only two vertical half-cylinders, as shown in Figure 2. The performance of Savonius rotors is significantly affected by the ratio of the rotor height $(\mathrm{H})$ and the rotor diameter (D). In addition, the performance of the engine is influenced by overlap $(\beta)$ that can be expressed as $\beta=(e-a) / d$, where $e$ is the interspace, $a$ is the shaft diameter and $d$ is the blade diameter. Savonius rotor performances have been studied by many researchers from 1977 to 2010, to determine the optimal design parameters of the rotor (Mahmoud, et al., 2012, p.19).

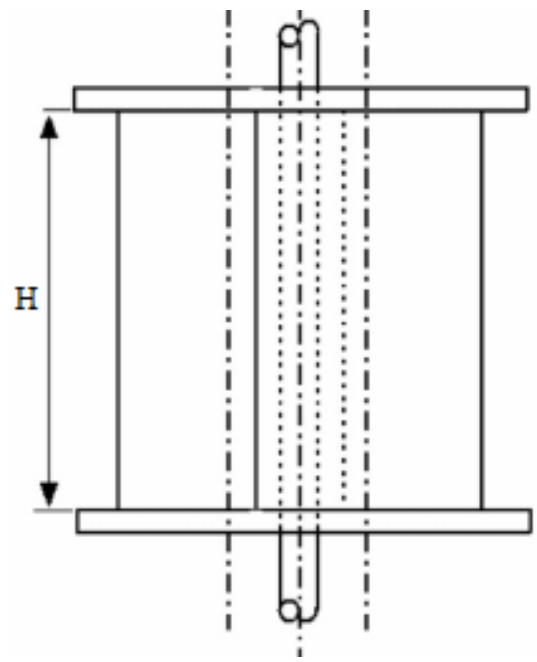

a)

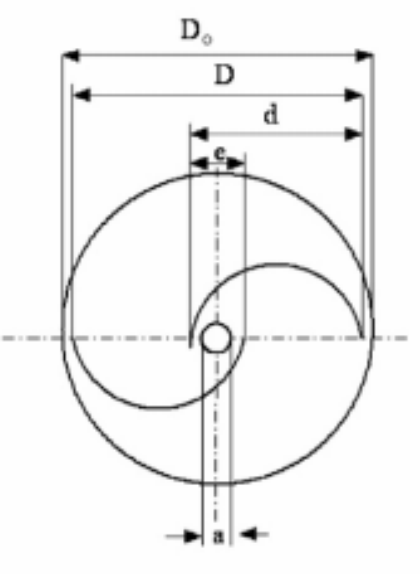

b)

Figure 2 - Scheme of the single Savonius rotor: (a) a side view; (b) top view Puc. 2 - Схема ротора Савониуса: (а) вид сбоку; (b) вид сверху Слика 2 - Шема јединственог Савониусовог ротора:

(a) поглед са стране; (b) поглед одозго 
The efficiency of the Savonius rotor is, however, lower than that of other wind turbines. The reason for its low efficiency is mainly that, at the time of one rotation, one rotor blade moves against the wind while the other moves in the direction of the wind. However, with the advantages of its simple design and low cost of construction, the Savonius rotor is mainly used for water pumping and ventilation on a small scale (Kunio, Jitendro, 2007, p.580).

The Savonius rotor performance power $\left(C_{p} \approx 15 \%\right)$ is rather low compared to those windmills with a horizontal axis $\left(\mathrm{C}_{\mathrm{p}} \approx 45 \%\right)$ and to Darius-type windmills with a vertical axis $\left(\mathrm{C}_{\mathrm{P}} \approx 35 \%\right)$ (Burçin, et al., 2008a, p.1673).

In the literature, there are available various studies conducted in order to increase the performance of Savonius rotors. A lot of theoretical and experimental research has been done with the aim of improving the aero-dynamic performances of the Savonius rotor (Burçin, Mehmet, 2010, p.821). In these studies, many scientists have experimentally and numerically examined the effects of various Savonius rotor design parameters, such as the ratio of the rotor dimensions, overlapping and the space between the rotor blades, the profile of the blade cross section, the number of blades, and the presence or absence of the end plates of the rotor. Many experimental and numerical studies have been conducted on the Savonius rotor to investigate the velocity field and the pressure on the blades. There are also some other studies for the design and development of small Savonius rotors for the local production of electricity (Burçin, et al., 2008a, p.1673).

A conventional Savonius rotor is provided with blades made of two half-cylinders in rotation about the vertical axis, with or without interspaces (Burçin, et al., 2008a, p.1674). The Savonius rotor is classified as a vertical axis turbine whose working principle is mainly based on the difference in resistance between the convex and concave parts of the blades (Dobrev, Fawaz, 2011, p.712). Wind power exert pressure to both the convex blade and the concave blade as shown in Figure 3. 

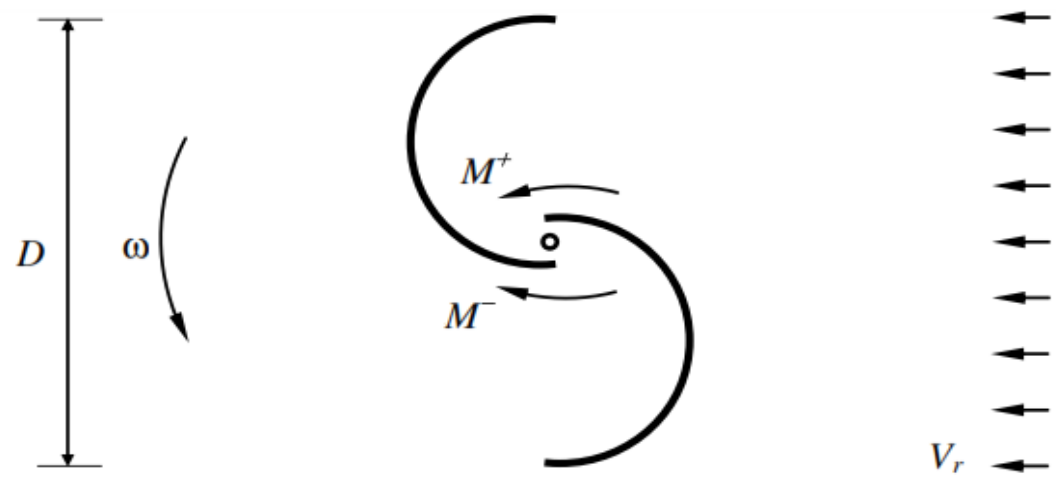

In this paper, an experimental study was carried out and the following geometric parameters of the Savonius rotor were taken into account:

The rotor diameter (D) and the rotor height $(H)$ are $32 \mathrm{~cm}$ and, in accordance with the optimal ratio of $e / d=0.15$, the interspace $(e)$ is $2.6 \mathrm{~cm}$. The thickness of the blades is $2 \mathrm{~mm}$. Two end plates are made of $4 \mathrm{~mm}$ thick steel plates with a plate diameter $\left(D_{0}\right)$ of $35.2 \mathrm{~cm}$. The Savonius rotor shaft is attached at the top and the bottom with ball bearings to reduce friction forces to a minimum. The rotor is attached to the experimental setting with ties to facilitate assembly and disassembly (Burçin, et al., 2008a, p.1674).

The Savonius rotor with the wind inlet was designed to improve the low aerodynamic performances of the Savonius rotor. This design is both 
simple and inexpensive, and consists of flat plate sheets. This wind inlet is used to turn the wind impinging on the front of the rotor and guide it to the rotor (Burçin, Mehmet, 2010, p.822). The aim of this study was to make and then analyze changes in the angles of the upper and lower plates of the wind inlet without changing the basic structure of the Savonius rotor to improve performances and increase the efficiency of the rotor. In this study, a wind inlet is used to direct wind and it is of simple construction (Burçin, et al., 2008a, p.1673).

The wind inlet with its geometric parameters is illustrated in Figure 4. The parts of the wind inlet ( $a$ and $b$ curtains) are plates that deflect the wind as shown in Figures 4 and 5 . The construction of these rejection panels is simple and cheap, because they are made from flat sheet plates (Burçin, et al., 2008a, p.1674).

A series of experiments was performed with and without curtains to test the performances. The experiments for the wind inlet angles were conducted with values $\alpha=45^{\circ}$ and $\beta=15^{\circ}$, and the length of the curtains was $l_{1}=45 \mathrm{~cm}, I_{2}=52 \mathrm{~cm}$, as the best results (Burçin, et al., 2008a, pp.1675-1676).
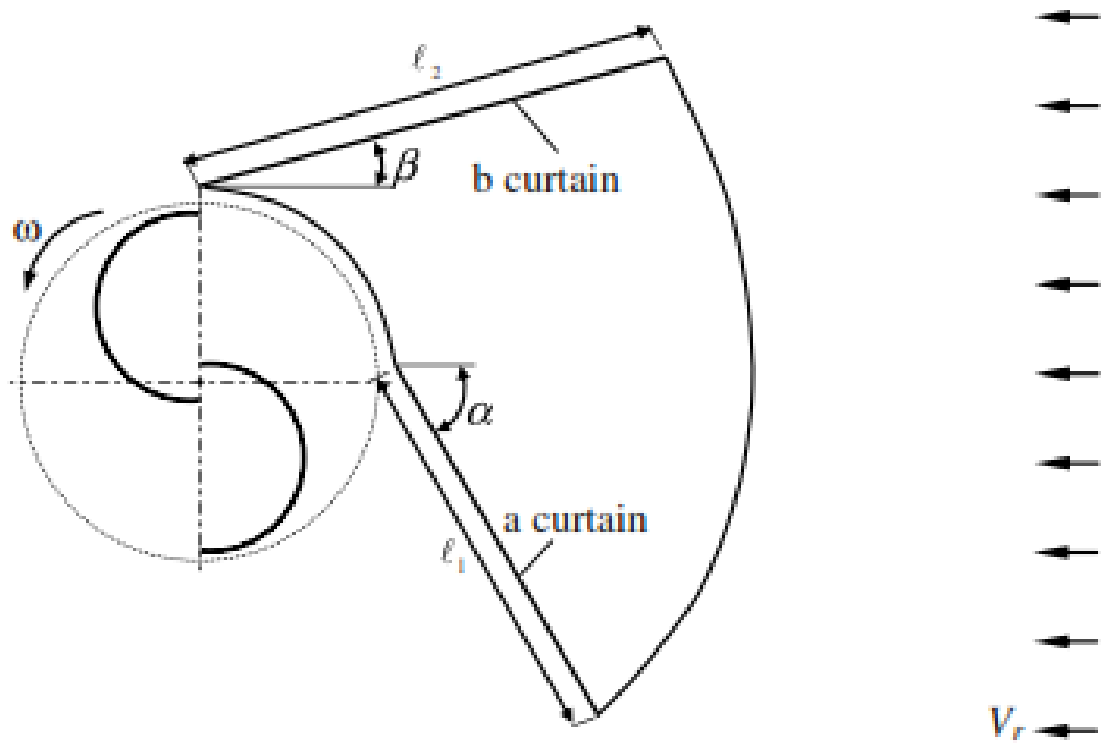

Figure 4-Geometric parameters of the wind inlet Puc. 4 - Геометрические параметры конфузора Слика 4 - Геометријски параметри уводника за ветар 


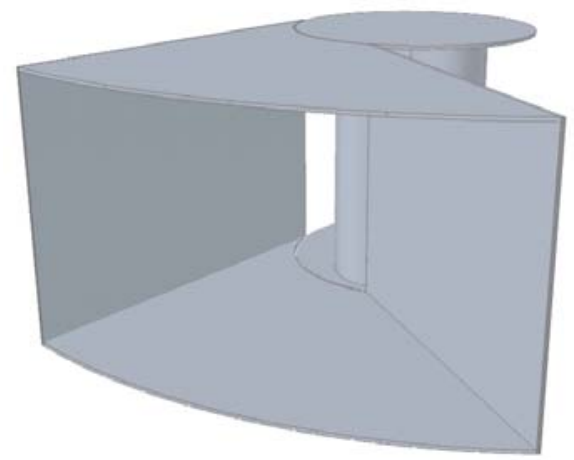

Figure 5 - Savonius rotor with the wind inlet, where the vertical angle of the upper and the lower plate is zero degrees

Puc. 5 - Ротор Савониуса с конфузором, вертикальный угол верхней и нижней стенки которого составляет $0^{\circ}$

Слика 5 - Савониусов ротор са уводником за ветар, где је вертикални угао горње и доње плоче нула степени

\section{Experimental setting and other equipment}

The experimental setting consists of a wind generator, a Savonius rotor, a wind inlet and measuring devices for measuring wind speed and number of revolutions. The wind generator (a fan) used in the experiments has a power of $1.5 \mathrm{~kW}$ and an outlet cross section diameter of $\phi=50 \mathrm{~cm}$. Wind speed can be changed using a built-in potentiometer on the fan motor whose revolution number control regulates the wind speed. The Savonius rotor, the wind inlet and the gauges are set away from the fan. The Savonius rotor and the wind inlet with the curtains are placed on a steel table. The Savonius rotor is connected at the upper and lower part with the steel structure by ball bearings to reduce friction force. The designed wind inlet is placed in front of the Savonius rotor. Wind speed and the number of revolutions are measured with a multifunction anemometer and a tachometer (tachometer). The MASTECH MS6250 anemometer with a measuring range from 0.4 to $30 \mathrm{~m} / \mathrm{s}$ was used to measure wind speed and the accuracy of the multifunctional anemometer is $\pm 0.2 \mathrm{~m} / \mathrm{s}$. Angular velocity is measured by the PCE DT-62 optical tachometer with a measuring range from +2 to $+99,999 \mathrm{rpm}$ with a precision of $\pm 0.05 \%+1$.

The Savonius rotor with the wind inlet is set at approximately $830 \mathrm{~cm}$ from the fan outlet cross section. The rotor with the wind inlet was installed in the same position for each measurement. The rotor with the wind inlet 
acts under the same wind speed conditions in order to compare the different angles of the upper and lower plate of the wind inlet.

The experiments were carried out at an average wind speed of $7 \mathrm{~m} / \mathrm{s}$ $\left(R e=1.5 \times 10^{5}\right)$ (Burçin, et al., 2008a, p.1675).

This speed of $7 \mathrm{~m} / \mathrm{s}$ was measured at a measuring grid attached at about $170 \mathrm{~cm}$ from the center of the Savonius rotor with the wind inlet.

\section{Experimental results}

A series of experiments was carried out with a gradual increase of the vertical angle of the upper and lower plate of the wind inlet of the Savonius rotor in order to determine the optimal angle which would improve the system performance. The angles of the lower and upper plate were equally increased and the angles of $15^{\circ}, 30^{\circ}, 60^{\circ}, 90^{\circ}$ and $120^{\circ}$ were tested. The total increase of the wind inlet upper and lower plate angles was marked with $\gamma$, the angle of the wind inlet upper plate was marked with $\gamma / 2$ and the angle of the wind inlet bottom plate with $\gamma / 2$. The angle of $0^{\circ}$ was first tested, which means that there is no increase in vertical angles of the wind inlet top and bottom plates. Then, the next testing was done with an angle of $15^{\circ}$, which means that the angle of the upper plate increased by $7.5^{\circ}$ and the angle of the bottom plate for $7.5^{\circ}$ giving a total of $15^{\circ}$. In this way, the test was conducted with other angles. Increasing the vertical angles of the upper and lower plates of the wind inlet of the Savonius rotor can be seen in Figure 6.

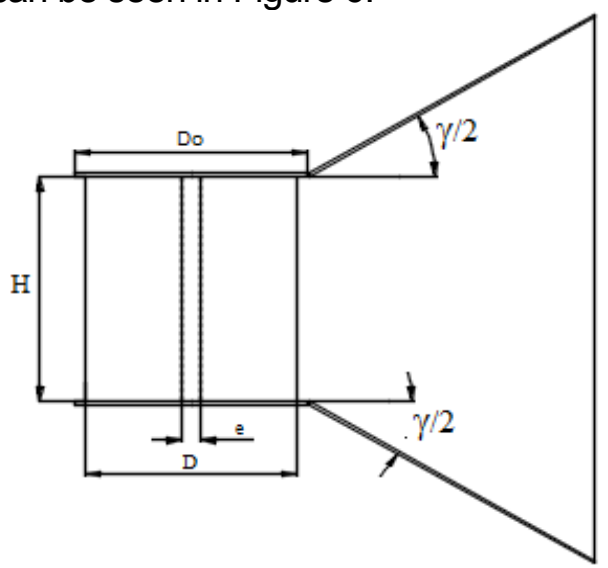

Figure 6 - Vertical change of the upper and lower angles of the wind inlet Puc. 6 - Вертикальное изменение угла верхней и нижней стенки конфузора для ветрового потока

Слика 6 - Вертикално померање угла горње и доње плоче уводника за ветар

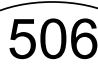




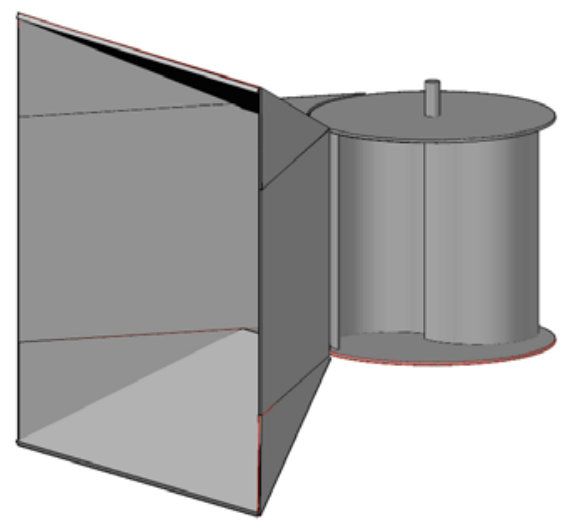

\section{Figure 7 - Vertical change of the wind inlet angles \\ Puc. 7 - Вертикальное изменение угла конфузора для ветрового потока} Слика 7 - Вертикално померање угла уводника за ветар

The test procedure for examining the performance of the Savonius rotor with increased vertical angles of the top and bottom plates on the wind inlet is as follows: after increasing the vertical angles of the upper and lower plates of the Savonius rotor wind inlet for $15^{\circ}$, an anemometer is placed at a distance of about $170 \mathrm{~cm}$ from the wind inlet. The speed of the wind created by a $50 \mathrm{~cm}$ diameter fan with a motor of $1.5 \mathrm{~kW}$ is then set at $7 \mathrm{~m} / \mathrm{s}$. An example of this procedure can be seen in Figure 8. Then, the tachometer is used to measure the number of revolutions of the Savonius rotor as shown in Figure 9. The same test procedure is repeated for other angles.

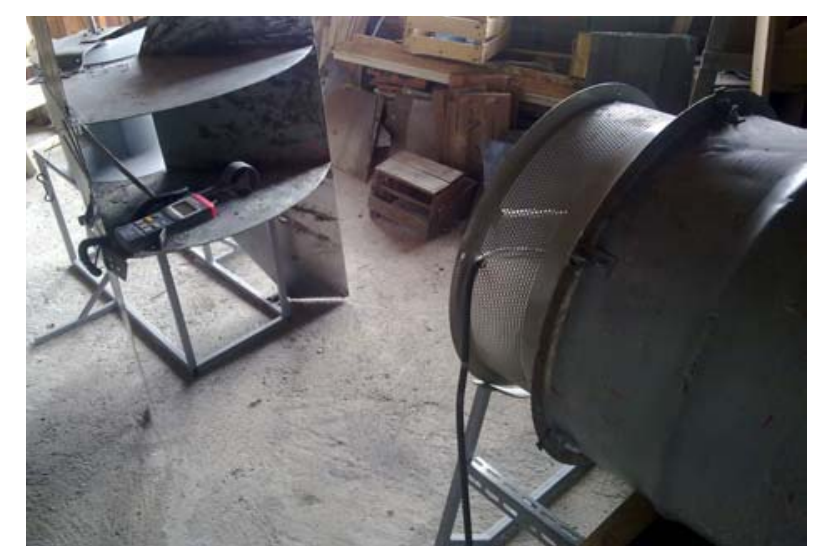

Figure 8 - The process of measuring the wind speed using an anemometer Puc. 8 - Измерение скорости ветра анемометром

Слика 8 - Поступак мерења брзине ветра помоћу анемометра 


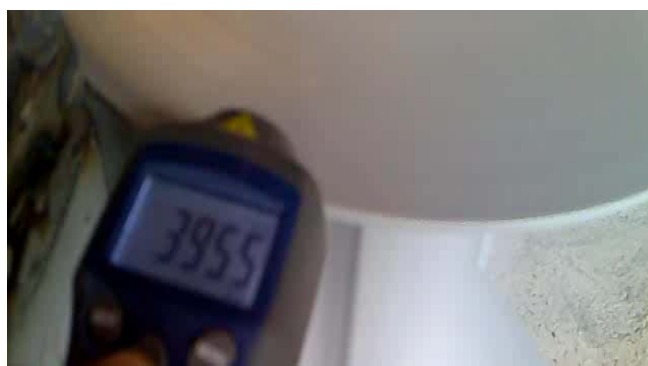

Figure 9 - Measurement of the number of rotor revolutions, where the vertical angle of the wind inlet is, in this case, increased for $15^{\circ}$

Puc. 9 - Измерение количества оборотов вращения ротора, при увеличении вертикального угла конфузора для ветрового потока на $15^{\circ}$

Слика 9 - Поступак мерења броја обртаја ротора, где је вертикални угао уводника за ветар у овом случају повећан за $15^{\circ}$

The results obtained after testing the vertical angles of the upper and lower plates of the wind inlet can be seen in Table 1 . It can be seen here that the vertical wind inlet angle of $15^{\circ}$ gives the best results with the maximum speed of $396 \% \mathrm{~min}$.

Table 1 - Rotor RPM measured at different vertical angles of the wind inlet Таблица 1 - Количество оборотов вращения ротора измерено под различными вертикальными углами конфузора для ветрового потока

Табела 1 - Број обртаја ротора мерен под различитим вертикалним угловима уводника за ветар

\begin{tabular}{|c|c|c|}
\hline \multirow{2}{*}{$\gamma\left(^{\circ}\right)$} & \multicolumn{2}{|c|}{$\boldsymbol{n}(\mathbf{r p m})$} \\
\cline { 2 - 3 } & Max & $\boldsymbol{m i n}$ \\
\hline 0 & 318 & 304 \\
\hline 15 & 396 & 388 \\
\hline 30 & 371 & 361 \\
\hline 60 & 330 & 322 \\
\hline 90 & 288 & 283 \\
\hline 120 & 230 & 227 \\
\hline
\end{tabular}

The effect of rotation speed depending on the vertical angle of the wind inlet can be seen in the diagram shown in Figure 10. Here one can clearly see that the angles of the upper and lower plates of the wind inlet of the Savonius rotor of $15^{\circ}, 30^{\circ}$ and $60^{\circ}$ give a higher number of revolutions of the rotor relative to the vertical angle of the upper and lower plates of 
the wind inlet of zero degrees, while, with increasing the angles of $90^{\circ}$ and $120^{\circ}$, rotation speed drops.

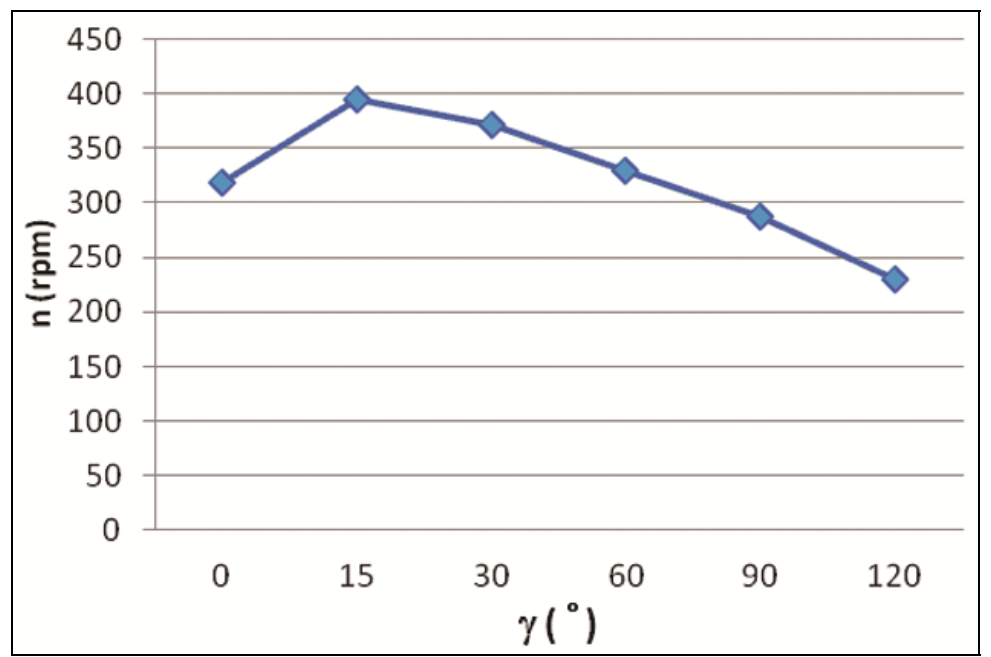

Figure 10 - Impact of the rotor rotation speed, taking into account different vertical angles of the wind inlet $\gamma$

Puc. 10 - Влияние скорости вращения ротора, с учетом разной величины вертикальных углов конфузора- $\gamma$

Слика 10 - Утицај брзине ротације ротора узимајући у обзир различите вертикалне углове уводника ветра $\gamma$

\section{Conclusion}

Due to high prices and limited resources of petroleum products which emit $\mathrm{CO}_{2}$ into the air in the combustion process thus contributing to the greenhouse effect, renewable energy sources appear as the only alternative to the existing energies. Due to the changes in the economic relations of production and consumption, today more attention is paid to the rational use of energy. Wind energy is a huge potential that can meet energy needs. Wind generators are used to convert wind energy into mechanical energy and for electricity production.

What was new in this paper was to analyze design changes and move the vertical angles of the upper and lower plates of the Savonius rotor wind inlet, which has enhanced the Savonius rotor performance. The designed wind inlet was placed in front of the rotor in order to prevent negative torque opposed to rotor rotation. The geometric parameters of the wind inlet were optimized in order to obtain optimal performances. The 
analysis found that the increase of the vertical angles of the upper and lower plates of the Savonius rotor wind inlet gives better results than using the classical wind inlet without increasing the vertical angles of the upper and lower plates. The angle of the upper and lower plates of the Savonius rotor wind inlet was gradually raised to $15^{\circ}, 30^{\circ}, 60^{\circ}, 90^{\circ}$ and $120^{\circ}$. It was found that the angles of $15^{\circ}, 30^{\circ}$ and $60^{\circ}$ give higher numbers of rotor revolutions in relation to the wind inlet of the Savonius rotor whose value of the angle of the upper and lower plate is zero degrees. It was also found that the number of revolutions drops with the angles of $90^{\circ}$ and $120^{\circ}$. The best results are obtained with increasing vertical angles of the top and bottom plates of the wind inlet of the Savonius rotor for $15^{\circ}$, where the rotor speed is $395 \% \mathrm{~min}$.

\section{References}

Burçin, D. A., Mehmet, A., Aydoğan, Ö., 2008a. An experimental study on improvement of a Savonius rotor performance with curtaining. Experimental Thermal and Fluid Science, 32(8), pp.1673-1678. Available at: http://dx.doi.org/10.1016/J.EXPTHERMFLUSCI.2008.06.006.

Burçin, D. A., Mehmet, A., 2008b. An experimental and numerical study on the improvement of the performance of Savonius wind rotor. Energy Conversion and Management, 49(12), pp.3425-3432.

Burçin, D. A., Mehmet, A., 2010. The use of a curtain design to increase the performance level of a Savonius wind rotors. Renewable Energy 35(4), pp.821-829.

Dobrev I., Fawaz M., 2011. CFD and PIV investigation of unsteady flow through Savonius wind turbine. Energy Procedia, 6, pp.711-720. Available at: http://dx.doi.org/10.1016/j.egypro.2011.05.081.

Frederikus, W., Andy, S., Hadi, S., 2015. An experimental study on the performance of Savonius wind turbines related with the number of blades. Energy Procedia, 68, pp.297-304. Available at: http://dx.doi.org/10.1016/j.egypro.2015.03.259.

Kunio, I., Jitendro, N.R., 2007. Characteristics of wind power on Savonius rotor using a guide-box tunnel. Experimental Thermal and Fluid Science, 32(2) pp.580-586.

Mahmoud, N.H., El-Haroun A.A., Wahba, E., Nasef, M.H., 2012. An experimental study on improvement of Savonius rotor performance. Alexandria Engineering Journal, 51(1), pp.19-25.

Terje, A.M., Susanne G.M., 2014. Intermodal transport of windmills. Transportation Research Procedia, 1(1), pp.197-205. 
УЛУЧШЕНИЯ ЭКСПЛУАТАЦИОННЫХ СВОЙСТВ КОНФУЗОРА РОТОРА САВОНИУСА

Деян Д. Динчич, Милан 3. Деспотович

Университет в г. Крагуевац, Факультет инжерных наук, г. Крагуевац,

Республика Сербия

ОБЛАСТЬ: энергетика и процессная техника

ВИД СТАТЬИ: профессиональная статья

ЯЗЫК СТАТЬИ: английский

Резюме:

В данной статье представлен анализ замены дизайна ротора Савониуса путем увеличения вертикальных углов верхней $и$ нижней стенки конфузора, произведенной в целях улучшения эксплуатационных свойств системы. Конфузор для вихревого потока размещается фрронтально для того чтобы предотвращать отрицательный крутящий момент противоположный вращению ротора. Анализ и испытания показали, что при учеличении вертикальных углов верхней и нижней стенки конфузора ротора Савониуса значительно улучшаются эксплуатационные свойства ротора. Выявлено, что наилучшие результаты достигаются при увеличении вертикальных углов верхней и нижней стенки конфрузора ротора Савониус на $15^{\circ}$ суммарно, при этом количество оборотов ротора docmuzaem $395 \%$ мин.

Ключевые слова: вертикальные углы, ветер, ротор Савониуса, роторы, стенки, конфузоры.

ПОБОљШАНЕ ПЕРФОРМАНСЕ УВОДНИКА

ЗА ВЕТАР САВОНИУСОВОГ РОТОРА

Дејан Д. Динчић, Милан 3. Деспотовић

Универзитет у Крагујевцу, Факултет инжењерских наука, Крагујевац,

Република Србија

ОБЛАСТ: енергетика и процесна техника

ВРСТА ЧЛАНКА: стручни чланак

ЈЕЗИК ЧЛАНКА: енглескИ

\section{Сажетак:}

У раду је извршена анализа промене дизајна кроз повећање вертикалних углова горње и доње плоче уводника за ветар Савониусовог ротора, са циљем да се добију бољи резултати и 
боље карактеристике система. Дизајн са уводником за ветар смештен је у предњем делу ротора како би се спречила негативна обртна сила супротна ротацији ротора. Геометријски параметри уводника за ветар су одређени како би се добиле оптималне перформансе. Анализом и испитивањем установљено је да се са повећањем вертикалних углова горње и доње плоче на уводнику за ветар Савониусовог ротора добијају боље перформансе ротора него само коришћењем класичног уводника за ветар. Утврђено је да се најбољи резултати постижу са повећањем вертикалних углова горње и доње плоче уводника за ветар Савониусовог ротора за укупно $15^{\circ}$, где се добија број обртаја ротора 395\%мин.

Кључне речи: вертикални углови, ветар, Савониусов ротор, ротори, плоче, уводници.

Paper received on / Дата получения работы / Датум пријема чланка: 04. 05. 2016.

Manuscript corrections submitted on / Дата получения исправленной версии работы / Датум достављања исправки рукописа: 11. 10. 2016.

Paper accepted for publishing on / Дата окончательного согласования работы / Датум коначног прихватања чланка за објављивање: 13. 10. 2016.

(C) 2017 The Authors. Published by Vojnotehnički glasnik / Military Technical Courier (www.vtg.mod.gov.rs, втг.мо.упр.срб). This article is an open access article distributed under the terms and conditions of the Creative Commons Attribution license (http://creativecommons.org/licenses/by/3.0/rs/).

() 2017 Авторы. Опубликовано в «Военно-технический вестник / Vojnotehnički glasnik / Military Technical Courier» (www.vtg.mod.gov.rs, втг.мо.упр.срб). Данная статья в открытом доступе и распространяется в соответствии с лицензией «Creative Commons» (http://creativecommons.org/licenses/by/3.0/rs/).

(c) 2017 Аутори. Објавио Војнотехнички гласник / Vojnotehnički glasnik / Military Technical Courier (www.vtg.mod.gov.rs, втг.мо.упр.срб). Ово је чланак отвореног приступа и дистрибуира се у складу са Creative Commons licencom (http://creativecommons.org/licenses/by/3.0/rs/). 